\title{
Insight into Therapeutic Role of Plant-derived Medicines in Thyroid Dysfunction
}

\author{
Maaria Anwaar, Hafiz Muhammad Farhan Rasheed and Qaiser Jabeen* \\ Department of Pharmacology, The Islamia University of Bahawalpur, Pakistan
}

*Corresponding author: Qaiser Jabeen, Chairperson, Department of Pharmacology, Faculty of Pharmacy, The Islamia University of Bahawalpur, Pakistan.

To Cite This Article: Maaria Anwaar, Hafiz Muhammad Farhan Rasheed and Qaiser Jabeen. Insight into Therapeutic Role of Plant-derived Medicines in Thyroid Dysfunction. Am J Biomed Sci \& Res. 2021 - 12(6). AJBSR.MS.ID.001802. DOI: 10.34297/AJBSR.2021.12.001802.

Received: 眥 March 29, 2021; Published: 眥 May 07, 2021

\begin{abstract}
Endocrine disorders are very common in Asia of which the thyroid dysfunction (TD) represents a major subset. The prevalence of TD is rising to an alarming rate. The thyroid gland (TG) is morphologically a butterfly-shaped organ, located anterior to the trachea, just inferior to the larynx and flanked by wing-shaped left and right lobes with the medial region called isthmus. TG produces thyroid hormones (TH), mainly triiodothyronine (T3) and thyroxine (T4). TH action is mediated by multiple TH receptors belonging to a nuclear receptor superfamily that also includes receptors for other small lipophilic hormones. TH receptors function by binding to specific TH-responsive sequences in promoters of target genes and by regulating transcription. Regulation of TH is followed by the hypothalamic-pituitary-thyroid axis. TD can be due to overproduction or under production of TH; i.e. hyperthyroidism and hypothyroidism respectively. Hyperthyroidism is characterized by weight loss, heat intolerance, palpitation, increased sweating, warm soft skin, increased heart rate and blood pressure. Whereas; in hypothyroidism, the facial expressions become dull, the voice becomes husky, speech is slow, the eyes and face become puffy. Hormone replacement therapy has been a standard approach to TD. However, herbal approach for the treatment of thyroid dysfunction is gaining popularity as it is proved to be effective, safe and devoid of any or at least lesser side effects. According to the world health organization (WHO), about three-quarters of the world population depends upon natural remedies, including herbal medicine. Plants possess several secondary metabolites like phenols, phenolic acids, flavonoids, alkaloids, tannins, quinones, coumarins, saponins, terpenoids, triterpenoids, glycosides and organic acids, which affect thyroid dysfunction by different mechanisms. Therefore, this review aims to provide comprehensive information regarding various herbal drugs used in the management of thyroid dysfunction.
\end{abstract}

Keywords: Endocrine system, Thyroid gland, Hyperthyroidism, Hypothyroidism, T3 (Triiodothyronine), T4 (Thyroxine), TSH (Thyroid Stimulating Hormone), TPO (Thyroperoxidase), Natural products

\section{Introduction}

\section{Endocrine system}

Endocrine system comprises of the endocrine glands and the hormones they produce; and it is intimately related to the hormone secretion, its actions and principles of feedback mechanisms [1,2]. Endocrine glands are richly vascularized, ductless organs that secrete hormones into the interstitial spaces and circulatory system. Endocrine system maintains homeostasis through the collaborative function of various endocrine glands, including pituitary gland, thyroid gland, parathyroid gland, adrenal gland, gonads, pancreas, gut endocrine cells and adipose tissues [3]. Endocrine glands not only communicate with each other but are also linked with immune system, stress system and gut microbial flora. All this communication occurs through chemical mediators called hormones [4].

\section{Thyroid gland}

The thyroid gland is morphologically a butterfly-shaped organ, located anterior to the trachea, just inferior to the larynx. It is flanked by wing-shaped left and right lobes and the medial region called isthmus [5]. The thyroid gland produces thyroid hormones, mainly triiodothyronine (T3) and thyroxine (T4). Thyroid hormone action is mediated by multiple thyroid hormone receptor isoforms derived from two distinct genes. The thyroid hormone receptors belong to a nuclear receptor superfamily that also includes receptors for other small lipophilic hormones. Thyroid hormone receptors function 
by binding to specific thyroid hormone-responsive sequences in promoters of target genes and by regulating transcription. Regulation of thyroid hormone is followed by the hypothalamicpituitary-thyroid axis [6]. Thyroid hormone exerts both positive and negative feedback mechanism by the hypothalamus as well as anterior pituitary, which controls the release of both TRH from hypothalamus and TSH from anterior pituitary gland [7].

\section{Thyroid dysfunction}

Thyroid disease is very common worldwide affecting 5-15\% of general population. Women are 3-4 times more susceptible to experience any type of thyroid disease. Thyroid dysfunction can be due to overproduction or under production of thyroid hormones; i.e. hyperthyroidism and hypothyroidism respectively. Hyperthyroidism is characterized by weight loss, heat intolerance, warm soft skin, increased heart rate and blood pressure, palpitation and hyper-sweating. Hyperthyroidism can be caused by graves' disease, painless thyroiditis or postpartum thyroiditis, painful subacute thyroiditis, toxic multinodular goiter or toxic adenoma and exogenous thyroid hormone excess [8]. Whereas, hypothyroidism is characterized by dull facial expressions, husky voice, slow speech, puffy eyes and face. The clinical manifestations of hypothyroidism include cretinism and myxedema [9]. Diagnosis of thyroid dysfunction is based on the clinical features and laboratory findings of T3, T4 and TSH [10]. Healthcare physicians follow the guidelines of the "American Thyroid Association" for the management of thyroid disorders [11]. Pharmacological treatment of thyroid dysfunction varies according to the condition. Levothyroxine sodium is the drug of choice for the management of hypothyroidism $[12,13]$. Whereas the treatment of hyperthyroidism includes antithyroid drugs; i.e. propylthiouracil, carbimazole, methimazole, radioactive iodine and thyroidectomy $[14,15]$.

\section{Natural products in medicine}

According to the world health organization (WHO), about three-quarters of the world population depends upon natural remedies, including herbal medicine [16]. Throughout the entire history, natural products including plants, marine organisms, animal products and products of microorganism fermentation have been used in traditional medicines. This historical experience with natural products as therapeutic agents has evolved to isolate active chemical constituents from ethnopharmacological plants which help in further drug discovery [17]. The traditional Chinese medicine, Kampo, Ayurveda, traditional Korean medicine and Unani have been practiced in different areas of the world and played a great role into the wellbeing of mankind since centuries. Natural products, which evolved millions of years ago, have a unique chemical diversity, which results in diversity in their biological activities and drug-like properties. These products have become one of the most important source for developing new lead compounds. Their efficacy is related to the complexity of their well-organized three-dimensional chemical and steric properties, which offer many advantages in terms of efficiency and selectivity of molecular targets. As a successful example of drug development from natural products, artemisinin and its analogs are presently in wide use for malaria treatment. This shows how research using natural products has made a significant contribution in drug development [18].

The use of plants for the management and treatment of various health disorders is very common worldwide. People utilize various parts; i.e. leaves, bark, flowers, fruits and stalks of the plants [16]. Whereas, biological oils and venoms are also used for various ailments. Insulin, heparin, adrenaline, thyroxin, musk, beeswax, enzymes, and antitoxins sera are some examples of drugs obtained from animal sources. Fermentation is an indispensable traditional technology for improving the efficacy or reducing adverse effects of herbal medicines. The fermentation process has been shown to improve biological properties of plants, vegetables, and herbs. More specifically, fermentation causes decomposition and biotransformation of complex substrates into compatible components, thereby modulating product properties or changing the quantity of certain bioactive compounds [19].

\section{Plants and thyroid dysfunction}

Plants possess several secondary metabolites like phenols, phenolic acids, flavonoids, alkaloids, tannins, quinones, coumarins, saponins, terpenoids, triterpenoids, glycosides and organic acids which affect the biological system in different ways [20]. Flavonoids are polyphenolic compounds of natural occurrence produced by plants that are largely consumed for therapeutic purposes. Experimental data have shown that many flavonoids could inhibit thyroperoxidase activity, decreasing thyroid hormones levels thus increasing TSH and causing goiter. In thyroid tumor cell line, flavonoids were shown to inhibit cell growth, but they can also decrease radioiodine uptake and that could reduce the efficacy of radioiodine therapy. Flavonoids also affect the availability of thyroid hormones to target tissues, by inhibiting deiodinase activity or displacing T4 from transthyretin. Thus, flavonoids have been shown to interfere with many aspects of the thyroid hormones synthesis and availability in in vivo and in vitro models [21]. Thyroid peroxidase, also called thyroperoxidase (TPO) or iodide peroxidase, is an enzyme participating in the synthesis of thyroid hormones, which is reported to be inhibited by polyphenolic compounds [22] (Table 1). 
Table 1: Various Plants Reported to Possess Therapeutic Efficacy against Thyroid Dysfunction.

\begin{tabular}{|c|c|c|c|c|c|}
\hline Plant & Part Used & Extraction Method & Animal Model & Parameters Observed & Reference \\
\hline \multicolumn{6}{|c|}{ Plants Used Against Hyperthyroidism } \\
\hline $\begin{array}{l}\text { Aegle marmelos (L.) } \\
\text { Corrêa }\end{array}$ & Leaves & $\begin{array}{l}28 \% \text { Aqueous extract by } \\
\text { boiling }\end{array}$ & $1.0 \mathrm{~g} / \mathrm{kg}$ for 15 days & $\mathrm{T} 3, \mathrm{~T} 4$ & {$[27]$} \\
\hline Allium sativum L. & Bulbs & Dry powder by lyophilization & $\begin{array}{l}\text { L-thyroxine }(300 \mu \mathrm{g} / \mathrm{kg} / \mathrm{d} \text { for } \\
12 \text { consecutive days) induced } \\
\text { hyperthyroidism }\end{array}$ & TSH, T3, T4 & {$[28]$} \\
\hline \multirow[b]{2}{*}{ Aloe vera (L.) Burm.f. } & Parenchyma & $\begin{array}{l}10 \% \text { Aqueous extract by } \\
\text { blending and centrifugation }\end{array}$ & $125 \mathrm{mg} / \mathrm{kg}$ for 15 days & $\mathrm{T} 3, \mathrm{~T} 4$ & {$[27]$} \\
\hline & Gel & $\begin{array}{l}\text { Petroleum ether, chloroform } \\
\text { and methanolic extract by } \\
\text { maceration and evaporation }\end{array}$ & $\begin{array}{l}\text { L-thyroxin }(0.5 \mathrm{mg} / \mathrm{kg} \text {, } \\
\text { i.p for } 14 \text { days) induced } \\
\text { hyperthyroidism }\end{array}$ & $\mathrm{TSH}, \mathrm{T} 3, \mathrm{~T} 4$ & {$[29]$} \\
\hline Althaea officinalis L. & Flowers & $\begin{array}{l}\text { Hydro-alcoholic extract by } \\
\text { evaporation }\end{array}$ & $\begin{array}{l}\text { Scopoletin (7-hydroxy-6- } \\
\text { methoxy coumarin) } 1.00 \mathrm{mg} / \\
\text { kg, p.o. daily for } 7 \text { days }\end{array}$ & $\begin{array}{l}\text { TSH, T3, T4, lipid } \\
\text { peroxidation and } \\
\text { blood glucose }\end{array}$ & {$[30]$} \\
\hline Carica papaya L. & Seeds & $\begin{array}{l}96 \% \text { Ethanolic extract by } \\
\text { evaporation }\end{array}$ & $\begin{array}{c}50,200 \mathrm{mg} / \mathrm{kg} \text {, p.o extract for } 1 \\
\text { and } 8 \text { weeks }\end{array}$ & Pituitary and thyroids & {$[31]$} \\
\hline $\begin{array}{l}\text { Emblica officinalis } \\
\text { Gaertn }\end{array}$ & Fruits & $\begin{array}{l}\text { 95\% ethanolic extract by } \\
\text { soxhlation }\end{array}$ & $\begin{array}{c}\text { L-thyroxine }(0.5 \mathrm{mg} / \mathrm{kg} / \\
\text { day, i.p for } 30 \text { days }) \text { induced } \\
\text { hyperthyroidism }\end{array}$ & $\begin{array}{l}\text { T3, T4, hepatic LPO, } \\
\text { SOD and CAT }\end{array}$ & {$[32]$} \\
\hline Moringa oleifera Lam. & Leaves & $\begin{array}{c}\text { Aqueous extract by } \\
\text { evaporation }\end{array}$ & $\begin{array}{c}350 \mathrm{mg} / \mathrm{kg} / 0.2 \mathrm{ml} / \text { day for } 10 \\
\text { days }\end{array}$ & $\mathrm{T} 3, \mathrm{~T} 4$ & {$[27]$} \\
\hline Nigella sativa L. & Dry seeds & $\begin{array}{l}96 \% \text { Ethanolic extract by } \\
\text { evaporation }\end{array}$ & $\begin{array}{l}\text { Alloxan monohydrate }(150 \mathrm{mg} / \\
\mathrm{kg} \text {, i.p once) induced diabetes + } \\
1 \mathrm{~g} / \mathrm{kg} \text { extract for } 14 \text { day }\end{array}$ & TSH, T3, T4 & {$[23]$} \\
\hline $\begin{array}{l}\text { Trigonella foenum- } \\
\text { graecum L. }\end{array}$ & Seeds & $\begin{array}{l}\text { Powder extracted with } \\
20 \% \text { ethanol by the cold } \\
\text { percolation }\end{array}$ & $\begin{array}{l}\text { L-thyroxine ( } 300 \mu \mathrm{g} / \mathrm{kg} \text { body } \\
\text { wt./d for } 12 \text { consecutive days) } \\
\text { induced hyperthyroidism }\end{array}$ & TSH, T3, T4 & {$[28]$} \\
\hline \multicolumn{6}{|c|}{ Plants Used Against Hypothyroidism } \\
\hline $\begin{array}{c}\text { Bacopa monnieri (L.) } \\
\text { Wettst. }\end{array}$ & Leaves & $\begin{array}{c}50 \% \text { ethanolic extract by } \\
\text { evaporation }\end{array}$ & $\begin{array}{l}\text { PTU (10 mg/kg) + } 200 \mathrm{mg} / \mathrm{kg} \\
\text { for } 15 \text { days }\end{array}$ & $\mathrm{T} 3, \mathrm{~T} 4$ & {$[27]$} \\
\hline Citrullus vulgaris & Dried peels & $\begin{array}{l}\text { Methanolic extract by } \\
\text { evaporation }\end{array}$ & $\begin{array}{c}\text { PTU (10 mg/kg/day, i.p } \\
\text { for } 10 \text { days) induced } \\
\text { hypothyroidism+ } 100 \mathrm{mg} / \mathrm{kg} \text {, } \\
\text { p.o for } 10 \text { days }\end{array}$ & $\begin{array}{l}\text { T3, T4, fasting glucose, } \\
\text { serum insulin and } \\
\text { tissue peroxidation }\end{array}$ & {$[34]$} \\
\hline Cucumis melo L. & Dried peels & $\begin{array}{l}\text { Methanolic extract by } \\
\text { evaporation }\end{array}$ & $\begin{array}{c}\text { PTU }(10 \mathrm{mg} / \mathrm{kg} / \text { day, i.p } \\
\text { for } 10 \text { days) induced } \\
\text { hypothyroidism+ } 100 \mathrm{mg} / \mathrm{kg} \text {, } \\
\text { p.o for } 10 \text { days }\end{array}$ & $\begin{array}{l}\text { T3, T4, fasting glucose, } \\
\text { serum insulin and } \\
\text { tissue peroxidation }\end{array}$ & {$[34]$} \\
\hline Curcuma longa L. & Rhizome & Curcumin & $\begin{array}{l}\text { Lithium carbonate }(14.4 \mathrm{mg} / \mathrm{kg} \\
\text { b.wt/day for } 6 \text { weeks) induced } \\
\text { thyroid dysfunction }\end{array}$ & $\begin{array}{c}\text { TSH, T3, T4, pro- } \\
\text { inflammatory } \\
\text { cytokines, thyroid lipid } \\
\text { nitric oxide and levels } \\
\text { peroxidation }\end{array}$ & {$[35]$} \\
\hline \multirow[t]{2}{*}{ Fucus vesiculosus L. } & Algae & $\begin{array}{l}\text { Aqueous extract and isolated } \\
\text { flavonoid }\end{array}$ & $\begin{array}{l}25,50 \text { and } 75 \mathrm{mg} / \mathrm{kg} / \text { day of } \\
\text { aqueous extract and } 25,50 \\
\text { and } 75 \mathrm{mg} / \mathrm{kg} / \text { day of isolated } \\
\text { flavonoids }\end{array}$ & TSH, T3, T4 & {$[36]$} \\
\hline & Whole Sea weed & Powder & $\begin{array}{l}\text { Propylthiouracil (15 mg/ } \\
\text { kg for } 3 \text { weeks) induced } \\
\text { hypothyroidism }\end{array}$ & $\mathrm{TSH}, \mathrm{T} 3, \mathrm{~T} 4$ & {$[37]$} \\
\hline Mangifera indica L. & Dried peels & $\begin{array}{l}\text { Methanolic extract by } \\
\text { evaporation }\end{array}$ & $\begin{array}{c}\text { PTU }(10 \mathrm{mg} / \mathrm{kg} / \text { day, i.p } \\
\text { for } 10 \text { days) induced } \\
\text { hypothyroidism+ } 200 \mathrm{mg} / \mathrm{kg} \text {, } \\
\text { p.o for } 10 \text { days }\end{array}$ & $\begin{array}{l}\text { T3, T4, fasting glucose, } \\
\text { serum insulin and } \\
\text { tissue peroxidation }\end{array}$ & {$[34]$} \\
\hline Mellissia Officinalis & Whole plant & $\begin{array}{l}96 \% \text { Ethanolic extract } \\
\text { by centrifugation and } \\
\text { evaporation }\end{array}$ & $\begin{array}{l}2 \% \text { Cholesterol added in diet } \\
\text { to induce Hypercholesterol } \\
\text { rat+treatment for } 21 \text { days }\end{array}$ & TSH, T3, T4 & {$[38]$} \\
\hline
\end{tabular}




\begin{tabular}{|c|c|c|c|c|c|}
\hline & Roots & Aqueous extract & $\begin{array}{c}1.4 \mathrm{~g} / \mathrm{kg} \text { body weight daily for } \\
20 \text { days }\end{array}$ & $\begin{array}{c}\mathrm{T} 3, \mathrm{~T} 4 \text { and lipid } \\
\text { peroxidation }\end{array}$ & [39] \\
\cline { 2 - 5 } $\begin{array}{c}\text { Withania somnifera } \\
\text { (L.) Dunal }\end{array}$ & Roots & $\begin{array}{c}\text { Aqueous methanolic extract } \\
\text { by evaporation }\end{array}$ & $\begin{array}{c}\text { Propylthiouracil (PTU, } \\
0.05 \% \mathrm{w} / \mathrm{v} \text { ) in drinking } \\
\text { water for 6 weeks) induced } \\
\text { hypothyroidism }\end{array}$ & $\begin{array}{c}\text { TSH, total T3, free T3, } \\
\text { free T4, total T4 and } \\
\text { serum glucose }\end{array}$ \\
[40,42] \\
\hline
\end{tabular}

Resveratrol, genistein and curcumin have been reported to reduce cell proliferation, viability and growth in diverse thyroid cancer cell lines [23]. Piperine, the main alkaloid of Piper nigrum fruits, reported to lower the serum levels of both the thyroid hormones, thyroxin (T4) and triiodothyronine (T3) [24]. Recently, a series of saponins are proved to exert their physiological activities through binding to nuclear receptors. As thyroid hormone receptors belong to nuclear receptor family, so saponins can alter thyroid hormone activity by binding to these receptors [25]. Quercetin, naringenin, p-coumaric acid, cinnamic acid and scopoletin are known to possess thyroid inhibitory properties [26]. Hence, different secondary metabolites affect thyroid dysfunction by different mechanisms.

\section{Conclusion}

The review provides comprehensive information regarding various herbal drugs used in the management of thyroid dysfunction, Hyperthyroidism and Hypothyroidism.

\section{Conflict of Interest}

Authors declare no conflict of interest.

\section{Author Contributions}

Ms. Maaria Anwaar is M.Phil. (Pharmacology) scholar and the article is a part of her research project. H.M. Farhan Rasheed is Ph.D. (Pharmacology) scholar who helped Maaria in article writeup. Prof. Dr. Qaiser Jabeen is the research supervisor of both the students and designed the project.

\section{References}

1. Petit WA, Adamec CA (2005) Introduction. The encyclopedia of endocrine diseases and disorders. Infobase Publishing: pp 9-20.

2. Yang $Q$ (2011) Harrison's endocrinology. The Yale Journal of Biology and medicine 84(4): 497-498.

3. Cowan M, Azpeleta C, Lopez OJF (2017) Rhythms in the endocrine system of fish: A review. Journal of Comparative Physiology B 187(8): 1057-1089.

4. Garcia RN (2018) The clandestine organs of the endocrine system. General and Comparative Endocrinology 257: 264-271.

5. Bhaigyabati T, Ramya J, Usha K (2012) Effect of methanolic extract of sweet corn silk on experimentally induced hyperthyroidism in swiss albino rats. International Research Journal of Pharmacy 3: 241-245.

6. Zhang J, Lazar MA (2000) The mechanism of action of thyroid hormones. Annual review of physiology 62: 439-66.

7. Chiamolera MI, Wondisford FE (2009) Thyrotropin-releasing hormone and the thyroid hormone feedback mechanism. Endocrinology 150(3): 1091-1096.
8. Hughes K, Eastman C (2021) Thyroid disease long term management of hyperthyroidism and hypothyroidism. Australian Journal for General Practitioners 50(1-2): 36-42.

9. David GY, Kevin RD, Lori SB (2012) Hypothyroidism: An update. South African Family Practice 86(3): 244-251.

10. Razvi S, Bhana S, Mrabeti S (2019) Challenges in interpreting thyroid stimulating hormone results in the diagnosis of thyroid dysfunction. Journal of thyroid research 2019.

11. Palace MR (2017) Perioperative management of thyroid dysfunction. Health services insights 10: 1178632916689677.

12. Chakera AJ, Pearce SH, Vaidya B (2012) Treatment for primary hypothyroidism: Current approaches and future possibilities. Drug design, development and therapy 6: 1-11.

13. Hueston WJ (2001) Treatment of hypothyroidism. Am Fam Physician 64: 1717.

14. Burch HB, Cooper DS (2015) Management of graves disease: A review. The Journal of the American Medical Association 314(23): 2544-2554.

15. Trepanier LA (2006) Medical management of hyperthyroidism. Clinical Techniques in Small Animal Practice 21: 22-28.

16. Gilani AH, Atta RU (2005) Trends in ethnopharmacology. Journal of ethnopharmacology 100(1-2): 43-49.

17. Shibata MA, Khan IA, Iinuma M, Shirai T (2012) Natural products for medicine. Journal of Biomedicine and Biotechnology 2012: 1.

18. Yuan H, Ma Q Ye L, Piao G (2016) The traditional medicine and modern medicine from natural products. Molecules 21(5): 559.

19. Hussain A, Bose S, Wang JH, Yadav MK, Mahajan GB, et al. (2016) Fermentation, a feasible strategy for enhancing bioactivity of herbal medicines. Food Research International 81: 1-16.

20. Ahmadu T, Ahmad K (2021) An introduction to bioactive natural products and general applications. Bioactive natural products for pharmaceutical applications. Springer: pp 41-91.

21. Dos SMCDS, Goncalves CFL, Vaisman M, Ferreira ACF, De CDP (2011) Impact of flavonoids on thyroid function. Food and Chemical Toxicology 49(10): 2495-2502.

22. Habza KE, Kaczor AA, Zuk J, Matosiuk D, Gawlik DU (2019) Thyroid peroxidase activity is inhibited by phenolic compounds-impact of interaction. Molecules 24(15): 2766.

23. Sharif SH, Elmahdi BM, Mohammed AMA, Mohammed AH (2012) The effects of nigella sativa l. Ethanolic extract on thyroid function in normal and alloxan-induced diabetic rats. Thyroid Research and Practice 9(2): 48.

24. Panda S, Kar A (2007) Amelioration of l-thyroxine-induced hyperthyroidism by coumarin (1,2-benzopyronone) in female rats. Clinical and experimental pharmacology and physiology 34(11): 12171219.

25. Zhang T, Zhong S, Li T, Zhang J (2020) Saponins as modulators of nuclear receptors. Critical reviews in food science and nutrition 60(1): 94-107.

26. Panda S, Sharma R, Khan A, Kar A (2020) Ameliorative effect of aloe gel against lt 4-induced hyperthyroidism via suppression of thyrotropin receptors, inflammation and oxidative stress. Molecular Biology Reports 47(4): 2801-2810. 
27. Kar A, Panda, S. and Bharti, S. (2002) Relative efficacy of three medicinal plant extracts in the alteration of thyroid hormone concentrations in male mice. Journal of ethnopharmacology 81(2): 281-285.

28. Tahiliani P, and Kar A (2000) Role of moringa oleifera leaf extract in the regulation of thyroid hormone status in adult male and female rats. Pharmacological research 41(3): 319-323.

29. Tahiliani P, Kar A (2003) The combined effects of trigonella and allium extracts in the regulation of hyperthyroidism in rats. Phytomedicine 10(8): 665-668.

30. Shah S A, Akhtar N, Akram M, Shah PA, Saeed T, et al. (2011) Pharmacological activity of althaea officinalis l. Journal of Medicinal Plants Research 5: 5662-5666.

31. Udoh P, Nju R, Udoh F (2004) Effect of carica papaya (paw-paw) seeds ethanolic extract on the pituitary, thyroid and parathyroid glands of male wistar rats. Global Journal of Pure and Applied Sciences 10(4): 515-517.

32. Panda S, Kar A (2003) Piperine lowers the serum concentrations of thyroid hormones, glucose and hepatic 5'd activity in adult male mice. Hormone and Metabolic Research 35(9): 523-526.

33. Sharifi RJ, Rajabi S, Martorell M, Lopez MD, Toro MT, et al. (2020) Plant natural products with anti-thyroid cancer activity Fitoterapia. 104640.

34. Parmar HS, Kar A (2009) Protective role of mangifera indica, cucumis melo and citrullus vulgaris peel extracts in chemically induced hypothyroidism. Chemico-Biological Interactions 177(3): 254-258.

35. Abd ESM, Manal HA (2016) Curcumin mitigates lithium-induced thyroid dysfunction by modulating antioxidant status, apoptosis and inflammatory cytokines. The Journal of Basic \& Applied Zoology 76: 7-19.
36. Hameed RR, Atya, KF, Mohameed MA (2014) Role of fucus vesiculosus 1 extract in the regulation of thyroid hormones status in adult male rabbits. Kerbala J Pharm Sci 5(7): 67-74.

37. Hatem RM, Almayali HK (2018) The effect of fucus vesiculosus on the function and structure of the thyroid gland of male rats treated with propylthiouracil. Journal of Pharmaceutical Sciences and Research 10(10): 2669-2673.

38. Zarei A, Changizi AS, Sokhandani M, Rezaei A, Zaheiri S, et al. (2013) Comparison between the effects of the alcholic extract of mellissia officinalis and atorvastatin on serum levels of thyroid hormones in hypercholesterolemic male rats. Zahedan Journal of Research in Medical Sciences 4(1): 15-23.

39. Verma SK, Kumar A (2011) Therapeutic uses of withania somnifera (ashwagandha) with a note on withanolides and its pharmacological actions. Asian Journal of Pharmaceutical and Clinical Research 4: 1-4.

40. Abdel WKG, Mourad HH, Mannaa FA, Morsy FA, Hassan LK, et al. (2019) Role of ashwagandha methanolic extract in the regulation of thyroid profile in hypothyroidism modeled rats. Molecular Biology Reports 46(4): 3637-3649.

41. Gan EH, Quinton R (2010) Physiological significance of the rhythmic secretion of hypothalamic and pituitary hormones. Progress in brain research 181: 111-126. 